\title{
Mengenal Lebih Dekat dengan Pendekatan Fenomenologi: Sebuah Penelitian Kualitatif
}

\author{
Oleh: Helaluddin
}

\section{A. PENDAHULUAN}

Dalam dunia akademik, istilah penelitian bukanlah hal yang baru. Penelitian telah diperkenalkan semenjak level pendidikan S-1 hingga S-3. Bahkan, dalam mencapai kelulusan pun mahasiswa harus melakukan penelitian baik berupa skripsi, tesis, maupun disertasi. Banyak mahasiswa yang terkendala dalam menyelesaikan studinya disebabkan oleh proses penelitian yang cenderung membutuhkan waktu yang relatif lama. Ada beberapa bentuk penelitian yang dipilih oleh mahasiswa pada umumnya, antara lain penelitian eksperimen, korelasi, Penelitian Tindakan Kelas (PTK) atau Penelitian Tindakan Sekolah (khusus mahasiswa Program Studi Pendidikan), Penelitian dan Pengembangan atau Research and Development ( $R$ \& $D)$, dan penelitian kualitatif. Semua bentuk penelitian tersebut bermuara pada dua kutub yang saling berseberangan (kalau boleh dikatakan demikian), yaitu penelitian kuantitatif dan penelitian kualitatif.

Bagi lingkungan kampus, penelitian merupakan kegiatan yang menjadi tupoksi seorang dosen. Kewajiban melaksanakan penelitian merupakan salah satu isi Tri Dharma Perguruan Tinggi. Bagi dosen, penelitian merupakan hal penting yang sangat berpengaruh pada perjalanan karir ke depan. Di samping sebagai tugas, penelitian juga berperan penting dalam proses kenaikan pangkat dan golongan. Artinya, kegiatan penelitian dapat diajukan menjadi poin atau kum dalam mengajukan kenaikan pangkat dan golongan tersebut.

Pada dasarnya, penelitian dilakukan bertujuan untuk mengembangkan atau menemukan ilmu pengetahuan. Pengetahuan yang dihasilkan sebuah penelitian di sini dapat berupa teori, penjelasan-penjelasan tentang fenomena atau sesuatu hal, dan dapat pula berupa pengetahuan tentang konsep-konsep atau pola-pola regulasi yang ada di duni ini. Di sisi lain, penelitian juga bertujuan untuk menemukan dan mengembangkan strategi-strategi yang dapat digunakan untuk memecahkan suatu masalah. Dalam bidang pendidikan dan pembelajaran misalnya, penelitian 
dilakukan dengan tujuan untuk membuktikan, menemukan, dan mengembangkan model, strategi, metode, dan perangkat pembelajaran.

Pada awal kemunculannya, penelitian kuantitatif yang berasal dari filsafat positivisme lebih jauh berkembang bila dibandingkan dengan penelitian kualitatif. Dengan situasi ini banyak yang beranggapan bahwa penelitian kuantitatif muncul lebih dulu daripada penelitian kualitatif. Padahal kenyataanya, kedua jenis penelitian ini muncul secara bersamaan. Namun sekitar dua puluhan tahun-an belakangan ini, penelitian kualitatif menunjukkan perkembangan yang luar biasa dalam dunia penelitian. Metode yang bersumber pada filsafat postpositivisme atau interpretivisme ini mulai dilirik dari berbagai disiplin ilmu, mulai dari sosiologi, psikologi, studi budaya hingga bidang humaniora seperti bahasa, seni, dan sastra.

Penelitian kuantitatif dan penelitian kualitatif memang meiliki perbedaan yang mendasar. Penelitian kuantitatif lebih disamakan dengan metode tradisional, positivistik, saintifik, dan konfirmasi sedangkan kualitatif lebih dicondongkan dengan istilah metode baru, postpositivistik, artistik, temuan, dan interpretif. Adapun kunci perbedaan pada kedua metode tersebut adalah fleksibiltasnya. Menurut Hashemnezhad (2015) penelitian kualitatif bersifat lebih fleksibel karena dalam studi ini membiarkan atau mempersilakan sikap spontanitas yang luar biasa dan adaptasi interaksi antara peneliti dan partisipan. Fleksibilitas ini dapat dilihat dari penggunaan pertanyaan terbuka yang mendorong partisipan merespons dengan bebas sesuai dengan bahasa mereka. Artinya, respons yang diperoleh tidak hanya sebatas jawaban "ya" atau "tidak". Di sisi lain, hubungan yang terjalin antara peneliti dan partisipan tidak bersifat formal tetapi cenderung santai dan akrab.

Perkembangan pesat penggunaan metode kualitatif tidak dapat dilepaskan dari animo masyarakat yang menggunakannya. Hal ini didasarkan pada keinginan dan kebutuhan masyarakat dalam menjawab segala kompleksitas permasalahan yang ada. Sebagai contoh, fenomena sikap individualis, pluralisasi, kecenderungan masyarakat, dan sikap yang terpengaruh konteks, dan lain-lainnya secara ilmiah memang tidak dapat dijelaskan secara tepat. Dengan penelitian kualitatif, diharapkan berbagai fenomena tersebut dapat dibuktikan secara alamiah dengan menggunakan metodenya. Singkatnya, berbagai fenomena tersebut tidak dapat dijelaskan dengan alur logika secara linear, terstandar, dan variabel tunggal yang ada pada metode kuantitatif.

Hadirnya metode penelitian gabungan (Mixed Methods) merupakan bentuk sikap terbuka bagi para peneliti kuantitatif terhadap munculnya metode penelitian kualitatif. Artinya, para peneliti kuantitatif kini telah melirik keberadaan metode kualitatif untuk digunakan. Pada kenyataannya, kehadiran metode gabungan ini masih menjadi kontroversi dari berbagai ahli. Namun yang perlu 
digarisbawahi bahwa pada hakikatnya keberadaannya saling melengkapi. Contoh perpaduan kedua analisis data tersebut digunakan pada penelitian dan pengembangan (Research and Development). Pada fase analisis kebutuhan, peneliti menggunakan metode kualitatif sedangkan pada fase uji coba produk digunakan metode kuantitatif.

Tren positif penggunaan metode kualitatif dan Mix Methods juga dikemukakan oleh Chareen L. Snelson (2016) dalam publikasinya di Amerika Serikat. la melakukan penelitian terhadap penggunaan metode kualitatif dan Mix methods pada media sosial pada kurun waktu 2007-2013. Dari 229 artikel penelitian kualitatif, ada 55 penelitian yang merupakan penelitian gabungan atau Mix Methods. Artikel-artikel tersebut dianalisis dan diulas dengan menggunakan pendekatan analisis konten (content analysis approach).

Selama ini banyak anggapan salah yang berkembang tentang penelitian. Bahkan yang lebih tragis, anggapan itu justru terbentuk dan terbangun dari lingkungan akademik. Masih ada beberapa oknum pendidik yang menganggap penelitian kuantitatif lebih tinggi tingkatannya dibandingkan penelitian kaulitatif. Pada ujungnya, mahasiswa banyak diarahkan oleh pembimbingnya ke penelitian kuantitatif. Di samping anggapan tentang strata atau tkasta tersebut, banyak dosen pembimbing yang cenderung tidak mempercayai mahasiswa untuk menggunakan metode kualitatif. Hal ini dilandasi oleh keyakinan bahwa pemahaman teori yang dipahami oleh mahasiswa dalam melaksanakan penelitiannya belum dianggap mumpuni. Kondisi seperti inilah yang harus segera diredefinisi oleh para pendidik. Karena pada hakikatnya, penelitian kuantitatif dan kualitatif memiliki kelebihan dan kekurangannya masing-masing. Poin kelebihan dan kekurangan tersebut harusnya dimunculkan sebagai dua metode penelitian yang saling melengkapi.

Paradigma kualitatif muncul dilatarbelakangi oleh pemikiran para peneliti yang tidak puas dengan hasil penelitian kuantitatif. Penelitian jenis ini dianggap tidak mampu menjawab semua permasalahan yang ada. Semula, penelitian kuantitatif dianggap sebagai metode penelitian yang baik karena memiliki alat-alat atau instrumen yang baik dan data yang diperoleh dianalisis secara statistik. Namun pada kenyataannya, data berupa angka-angka dan pengolahan secara matematis tidak mampu menjawab pertanyaan dan permasalahan secara meyakinkan.

Hal lain yang melatarbelakangi munculnya penelitian kualitatif adalah fenomena mendominasinya metode kuantitatif dalam dunia penelitian, khususnya ilmu-ilmu kemanusiaan dan budaya. Menurut Putra dan Dwilestari (2016) bahwa penelitian kuantitatif telah lama disadari tidak memadai lagi untuk menjelaskan tentang manusia dan kebudayaan. Kesadaran tersebut justru lahir dari para pengikut kuantitatif yang akhirnya bermuara pada munculnya filsafat 
postpositivisme yang melahirkan metode penelitian kualitatif. Dengan demikian, kualitatif menjadi metode penelitian yang memfokuskan diri pada manusia dan interaksinya dalam konteks sosial.

Hingga saat ini, masih banyak yang melabeli penelitian kualitatif dengan stigma negatif. Hal ini disebabkan oleh banyaknya peneliti kualitatif yang masih menggunakan cara memperoleh data dengan pola yang sederhana. Sebagai contoh, ada beberapa peneliti kualitatif yang menggunakan teknik wawancara, observasi, dan dokumentasi yang sederhana. Hal ini dilakukan dengan alasan singkatnya waktu, tenaga, dan biaya penelitian yang dimiliki. Hal lain ikut memperburuk adalah proses analisis data yang sekenanya. Dalam penelitian kualitatif, perolehan data yang terbaik dilakukan secara simultan atau berkali-kali hingga mencapai titik jenuh. Dengan situasi seperti ini, banyak orang menuding bahwa penelitian kualitatif tidak dapat dikatakan ilmiah (walau pada dasarnya penelitian bersifat alamiah). Simpulannya, diperlukan upaya dan usaha sungguh-sungguh dalam melaksanakan penelitian kualitatif agar hasil yang ditemukan akan menjadi jawaban dari segala permasalahan sosial yang terjadi dalam masyarakat.

\section{B. TEORI ANALISIS DATA KUALITATIF}

\section{Definisi, Tujuan, dan Karakteristik Metode Kualitatif}

Ada beberapa definisi tentang metode penelitian kualitatif yang dikemukakan oleh para ahli. Penelitian kualitatif didefinisikan sebagai metodologi yang menyediakan alat-alat dalam memahami arti secara mendalam yang berkaitan dengan fenomena yang kompleks dan prosesnya dalam praktik kehidupan sosial (Denzin dan Lincoln dikutip Brady: 2015). Definisi lain juga diutarakan oleh Strauss dan Corbin (2017) bahwa penelitian kualitatif merupakan jenis penelitian yang hasil temuannya tidak diperoleh melalui prosedur statistik atau bentuk hitungan lainnya. Lebih lanjut, Oun dan Bach (2014) menyebut metode kualitatif merupakan metode untuk menguji dan menjawab pertanyaan tentang bagaimana, dimana, apa, kapan, dan mengapa seseorang bertindak dengan cara-cara tertentu pada permasalahan yang spesifik.

Selanjutnya, metode kualitatif juga diartikan sebagai metode penelitian dalam mendeskrispsikan fenomena berdasarkan sudut pandang para informan, menemukan realita yang beragam dan mengembangkan pemahaman secara holistik tentang sebuah fenomena dalam konteks tertentu (Hilal dan Alabri: 2013). Senada dengan pendapat tersebut, Rovai dikutip Almalki (2016) menyebut metode kualitatif sebagai metode yang biasanya digunakan dalam menggambarkan secara induktif, dengan asumsi yang didasarkan pada konstruk realitas sosial, variabel yang sulit diukur, kompleks dan saling 
terkait, dan data yang dikumpulkan berisi tentang sudut pandang yang mendalam dari informan.

Hal senada juga dikemukakan oleh Burns dan Grove dikutip Khan (2014) yang menyebut definisi penelitian kualitatif sebagai sebuah sistem dan pendekatan subjektif untuk menjelaskan dan menyoroti pengalaman hidup sehari-hari. Menurutnya, setelah proses tadi maka dilanjutkan dengan tahapan memberi makna pada data yang ditemukannya. Dengan pendekatan kualitatif ini, peneliti dapat mengeksplorasi secara mendalam sikap-sikap manusia, perbedaan perspektif, dan pengalaman hidup untuk menemukan kompleksitas dalam situasi melalui kerangka secara menyeluruh (holistik).

Dari berbagai definisi di atas, secara umum dapat disimpulkan bahwa tujuan penelitian kualitatif untuk mendeskripsikan sebuah fenomena tertentu. Hal ini dikuatkan oleh pendapat Nassaji (2015) yang menyebut bahwa penelitian kualitatif atau penelitian deskriptif bertujuan untuk menggambarkan sebuah fenomena dengan berbagai karakter yang melingkupinya. Lebih lanjut, Nassaji juga menyebut bahwa penelitian ini lebih mementingkan apa daripada bagaimana dan mengapa sesuatu itu terjadi. Tujaun penelitian kualitatif juga dikemukakan oleh Sani, Manurung, Suswanto, dan Sudiran (2017) yang menyebut metode kualitatif bertujuan mengungkap fenomena yang ada serta memahami makna di balik fenomena tersebut.

Ada beberapa ciri-ciri atau karakterisktik yang dimiliki oleh penelitian kualitatif. Menurut Litchman dikutip Putra dan Dwilestari (2016) ada sepuluh ciri-ciri penelitian kualitatif, (1) yaitu description, understanding, and interpretation, (2) dynamic, (3) no single way of doing something, (4) inductive thinking, (5) holistic, (6) variety of data in natural setting, (7) role of the researcher. (8) in-depth study, (9) words, themes, and writing, dan (10) nonliniear. Di sisi lain, Bogdan \& Biklen dikutip Putra dan Dwilestari (2016) menyebut karakteristik penelitian kualitatif adalah naturalistic, descriptive data, concern with process, inductive, dan meaning.

Secara umum, ada beberapa tahapan yang harus dilalui dalam melakukan penelitian kualitatif. Dalam beberapa referensi, mungkin terdapat sedikit perbedaan tahapan namun pada dasarnya memliki prosedur yang sama. Menurut Newman (2014) ada beberapa tahapan dalam melakukan penelitian kualitatif, yaitu: (1) menyeleksi topik, (2) menyempitkan fokus pertanyaan artinya tahapan ini merupakan langkah krusial yang harus dilakukan agar topik yang masih luas dapat disempitkan dan lebih terfokus, (3) mendesain penelitian, (4) mengumpulkan data, (5) menganalisis data, (6) menginterpretasi data, dan (7) publikasi atau memberikan laporan penelitian kepada orang lain. 


\section{Jenis-jenis Penelitian Kualitatif}

Penelitian kualitatif dapat dikelompokkan menjadi beberapa jenis. Menurut Denzin \& Lincoln dikutip Irianto dan Subandi (2015) metode penelitian kualitatif terbagi atas pendekatan biografi, fenomenologi, studi kasus, grounded theory, dan etnografi. Di beberapa refenensi, jenis penelitian kualitatif juga berkembang menjadi beberapa pendekatan, selain yang telah disebutkan sebelumnya, pendekatan dalam penelitian kualitatif juga dapat berupa pendekatan etnometodologi, studi tokoh, studi teks, konten analisis, dan hermeneutika.

Salah satu pendekatan yang dibahas lebih lanjut dalam artikel ini adalah pendekatan fenomenologi. Ada pernyataan menarik dari Husserl yang berkaitan dengan penelitian kualitatif dan fenomenologi. Menurutnya, all qualitative research has a phenomenological aspect to it, but the phenomenological approach cannot be applied to all qualitative research. Artinya, semua penelitian kualitatif memiliki aspek fenomenologi di dalamnya, tetapi pendekatan fenomenologi tidak dapat diaplikasikan ke semua penelitian kualitatif (Padilla-Diaz: 2015).

Pada artikel ini, hanya dibahas tentang pendekatan fenomenologi dengan contoh aplikasinya dalam penelitian. Penelitian fenomenologi ini mejadi penelitian yang memiliki daya tarik tersendiri karena semakin banyak diminati oleh para peneliti dari berbagai disiplin ilmu. Pendekatan fenomenologi tidak hanya dillakukan oleh para peneliti pada bidang ilmu sosial tetapi juga merambah ke disiplin ilmu lainnya termasuk bidang pendidikan.

\section{Pendekatan Fenomenologi}

Secara harfiah, fenomenologi berasal dari kata pahainomenon dari bahasa Yunani yang berarti gejala atau segala sesuatu yang menampakkan diri. Istilah fenomena dapat dilihat dari dua sudut pandang, yaitu fenomena itu selalu menunjuk keluar dan fenomena dari sudut pandang kesadaran kita. Oleh karena itu, dalam memandang suatu fenomena kita harus terlebih dulu melihat penyaringan atau ratio, sehingga menemukan kesadaran yang sejati.

Sejarah awal mula munculnya filsafat fenomenologi berkembang pada abad ke-15 dan ke-16. Pada masa itu, terjadi perubahan besar dalam diri manusia tentang perspektif dirinya di dunia ini. Pada abad sebelumnya, manusia selalu memandang segala hal dari sudut pandang Ketuhanan. Selanjutnya, terjadilah gelombang besar modernitas pada kala itu yang mengubah sudut pandang pemikiran tersebut. Para filsuf banyak yang menolak 
doktrin-doktrin Gereja dan melakukan gerakan reformasi yang disebut sebagai masa pencerahan.

Paradigma ini muncul karena timbulnya pemikiran manusia terhadap subjektivitas. Yang dimaksud dengan subjektivitas di sini bukanlah antonim dari kata objektivitas. Subjek yang dimaksud merupakan makna "aku" yang ada dalam diri manusia yang menghendaki, bertindak, dan mengerti. Menurut Suseno dikutib Mujib (2015) manusia hadir ke dunia sebagai subjek yang memiliki kesadaran diri, tak hanya hadir sebagai benda di dunia ini, melainkan sebagai subjek yang berpikir, berefleksi, dan bertindak secara kritis dan bebas.

Fenomenologi ini berasal dari filsafat yang mengelilingi kesadaran manusia yang dicetuskan oleh Edmund Husserl (1859-1938) seorang filsuf Jerman. Pada awalnya teori ini digunakan pada ilmu-ilmu sosial. Menurut Husserl ada beberapa definisi fenomenologi, yaitu: (1) pengalaman subjektif atau fenomenologikal, dan (2) suatu studi tentang kesadaran dari perspektif pokok dari seseorang. Teori ini merupakan hasil dari perlawanan teori sebelumnya yang memandang sesuatu dari paradigma ketuhanan. Jadi secara sederhana, fenomenologi diartikan sebagai sebuah studi yang berupaya untuk menganalisis secara deskriptif dan introspektif tentang segala kesadaran bentuk manusia dan pengalamannya baik dalam aspek inderawi, konseptual, moral, estetis, dan religius. Lebih lanjut, Martin Heidegger berpendapat tentang fenomenologi Husserl (dalam Mujib: 2015) bahwa manusia tidak mungkin memiliki "kesadaran" jika tidak ada "lahan kesadaran", yaitu suatu tempat, panorama atau dunia agar "kesadaran" dapat terjadi di dalamnya yang berujung pada eksistensi yang bersifat duniawi.

Fenomenologi adalah pendekatan yang dimulai oleh Edmund Husserl dan dikembangkan oleh Martin Heidegger untuk memahami atau mempelajari pengalaman hidup manusia. Pendekatan ini berevolusi sebuah metode penelitian kualitatif yang matang dan dewasa selama beberapa dekade pada abad ke dua puluh. Fokus umum penelitian ini untuk memeriksa/meneliti esensi atau struktur pengalaman ke dalam kesadaran manusia (Tuffour: 2017).

Definisi fenomenologi juga diutarakan oleh beberapa pakar dan peneliti dalam studinya. Menurut Alase (2017) fenomenologi adalah sebuah metodologi kualitatif yang mengizinkan peneliti menerapkan dan mengaplikasikan kemampuan subjektivitas dan interpersonalnya dalam proses penelitian eksploratori. Kedua, definisi yang dikemukakan oleh Creswell dikutip Eddles-Hirsch (2015) yang menyatakan bahwa penelitian kualitatif adalah sebuah penelitian yang tertarik untuk menganalisis dan mendeskripsikan pengalaman sebuah fenomena individu dalam dunia sehari-hari. Sebagai contoh, studi 
fenomenologi tentang anorexia bagi beberapa orang yang terjadi dewasa ini. Anorexia merupakan gangguan (kalau dapat dikatakan demikian) makan yang dialami seseorang karena takut terhadap kenaikan berat badan yang disebabkan gaya hidup dan tuntutan budaya populer. Studi ini dapat ditekankan pada kondisi mengapa seseorang ingin seperti ini dan menginterpretasikan hidup mereka berdasarkan sudut padang yang mereka pahami. Studi ini bertujuan untuk memahami dan menggambarkan sebuah fenomena spesifik yang mendalam dan diperolehnya esensi dari pengalaman hidup partisipan pada suatu fenomena (Yuksel dan Yidirim: 2015).

Ada hal yang harus diperhatikan dalam penelitian kualitatif, khususnya yang menggunakan pendekatan fenomenologi. Banyak peneliti kontemporer yang mengklaim menggunakan pendekatan fenomenologi tetapi mereka jarang menghubungkan metode tersebut dengan prinsip dari filosofi fenomenologi (Sohn dkk: 2017). Hal ini perlu digarisbawahi agar kualitas penelitian fenomenologi yang dihasilkan memiliki nilai dan hasil standar yang tinggi. Untuk menuju ke hasil tersebut, penelitian fenomenologi harus memperhatikan ciri-ciri yang melingkupinya, yaitu: (1) mengacu pada kenyataan, (2) memahami arti peristiwa dan keterkaitannya dengan orang-orang yang berada dalam situasi tertentu, dan (3) memulai dengan diam.

Penelitian kualitatif dengan pendekatan fenomenologi juga memiliki karakteristik yang melekat di dalamnya. Menurut Mujib (2015) ada dua karakteristik dalam pendekatan fenomenologi dalam bidang agama. Pertama, pendekatan ini merupakan metode dalam memahami agama orang lain dalam perspektif netralitas. Dalam situasi ini, peneliti menggunakan preferensi orang bersangkutan untuk merekonstruksi dalam dan berdasarkan pengalaman orang tersebut. Artinya, dalam kondisi ini peneliti menanggalkan dirinya sendiri (epoche) dan berupaya membangun dari pengalaman orang lain. Kedua, dalam menggali data pada pendekatan ini dibantu denga disiplin ilmu yang lain, seperti sejarah, arkeologi, filologi, psikologi, sosiologi, studi sastra, bahasa, dan lain-lain.

Di samping beberapa poin pemaparan di atas, fenomenologi sebagai metode penelitian juga memiliki beberapa keuntungan atau kelebihan. Pertama, sebagai metode keilmuan, fenomenologi dapat mendeskripsikan dan menggambarkan suatu fenomena secara apa adanya tanpa memanipulasi data di dalamnya. Dalam kondisi ini, kita sebagai peneliti harus mengesampingkan terlebih dahulu pemahaman kita tentang agama, adat, dan ilmu pengetahuan agar pengetahuan dan kebenaran yang ditemukan benar-benar objektif. Kedua, metode ini memandang objek kajiannya sebagai sesuatu yang utuh dan tidak terpisah dengan objek lain. Artinya, pendekatan ini menekankan pada pendekatan 
yang holistik dan tidak parsial sehingga diperoleh pemahaman yang utuh tentang suatu objek. Dari beberapa kelebihan tersebut, studi fenomenologi juga memiliki masalah. Masalah tersebut diungkapkan oleh Sohn dkk (2017) yang menyatakan bahwa banyak peneliti kontemporer yang mengklaim menggunakan pendekatan fenomenologi tetapi pada kenyataanya mereka jarang menghubungkan metode tersebut dengan prinsip dari filosofi fenomenologi. Hal itulah yang seharusnya diperbaiki oleh para peneliti fenomenologi dewasa ini.

Pengumpulan data dari penelitian ini diperoleh dengan observasi dan wawanacara, termasuk dengan menggunakan wawancara mendalam atau in-depth interview. Wawancara mendalam ini digunakan untuk memperoleh mendetail tentang fenomena atau pendidikan yang diteliti. Wawancara jenis ini pula bertujuan untuk mendapatkan "sesuatu" dari yang belum terlihat. Data yang diperolah dari in-depth interview ini selanjutnya dianalisis dengan menggunakan Interpretative Phenomenological Analysis (IPA). Menurut Smith dikutip Bayir dan Limas (2016) ada beberapa tahapan dalam IPA, yaitu: (1) reading and re-reading, (2) initial noting, (3) developing emergent themes, (4) searching for connections acros emergent themes, (5) moving the next cases, dan (6) looking for patterns acros cases.

Analisis IPA merupakan metode untuk memahami "secara apa" dari sudut pandang partisipan untuk dapat berada di posisi sang partisipan tersebut. Analisis ini juga berupaya untuk "memahami" sesuatu, konteks memahami yang dimaksud memiliki dua makna, yaitu memahami interpretasi dalam arti mengidentifikasi atau berempati dan memahami dalam arti memaknai. Analisis IPA berupaya untuk memaknai sesuatu dari sisi partisipan dan dari sisi peneliti juga sehingga terjadilah kognisi pada posisi yang sentral.

IPA ini bertujuan untuk mengungkap secara detail bagaimana partisipan memaknai dunia pribadi dan sosialnya. Fokus utama studi fenomenologi ini adalah makna berbagai pengalaman, peristiwa, dan status yang dimiliki oleh partisipan. Studi ini juga berupaya untuk mengeksplorasi pengalaman personal dan memfokuskan pada persepsi atau pendapat individu tentang pengalaman pada objek atau peristiwa.

\section{IMPLEMENTASI}

Pada sub-bagian ini, akan dipaparkan ringkasan artikel penelitian kualitatif. Artkel ini berjudul Karena Hidup harus terus Berjalan (Sebuah Studi Fenomenologi Kehidupan Orang dengan HIVIAIDS) ditulis oleh Septiana Dewi Indriani dan Nailul Faiuziah (2017). Artikel ini dimuat dalam Jurnal Empati Volume 6 Nomor 1 pada Januari 2017. 


\section{Pendahuluan}

HIV atau Human Immunodeficiency Virus merupakan jenis virus yang menyerang sel darah putih pada manusia yang berefek pada penurunan sistem kekebalan tubuh. Dengan kondisi demikian manusia akan mudah terserang infeksi penyakit. AIDS (Acquired Immune Deficiency Syndrom) merupakan sekumpulan gejala penyakit yang timbul akibat melemahnya sistem kekebalan tubuh tersebut. Dari data Kementerian Kesehatan Indonesia pada tahun 2016 menunjukkan pola penularannya sangatb esar pada usia dewasa awal, yaitu rentang usia $20-40$ tahun.

Stigma dan diskriminasi terhadap para pengidap HIV/AIDS di masyarakat secara langsung akan berpengaruh buruk bagi psikologis. Kondisi ini akan menimbulkan rasa malu bagi para pengidap karena mereka merasa tidak mendapatkan dukungan secara moral dari lingkungannya. Di Indonesia, masih banyak terjadi pengucilan dan perlakuan yang berbeda dari masyarakat terhadap para pengidap HIV/AIDS. Dengan demikian, masalah HIV/AIDS bukan semata-mata masalah medis tetapi juga masalah stigma dan diskriminasi masyarakat atau lingkungan. Dengan tingginya angka pengidap HIV/AIDS dan stigma serta diskriminasi yang dialaminya, maka penelitian tentang pengalaman hidup orang-orang yang terjangkit penyakit tersebut menarik untuk diteliti. Tujuan dari penelitian ini adalah untuk mengetahui dan memahami dinamika psikologis pada kehidupan orang-orang dengan HIV/AIDS.

\section{Metode, Fokus, dan Partisipan Penelitian}

Penelitian ini merupakan penelitian kualitatif dengan perspektif fenomenologi. Studi fenomenologi merupakan sudut pandang yang fokus terhadap pengalaman-pengalaman individu dan interpretasi dunia. Femonenologi juga dimaknai sebagai metode dalam mencari makna-makna psikologis yang membentuk gejala melalui investigasi dan analisis contoh-contoh gejala yang dialami oleh partisipan.

Fokus penelitian ini adalah memahami dan mendeskripsikan dinamika psikologis dari pengalaman hidup bagi para pengidap HIV/AIDS. Dinamika psikologis yang dimaksud adalah masa sebelum terdiagnosis HIV/AIDS, masa pada saat terdiagnosis, masa pascaterdiagnosis, dan masa saat mengalami diskriminasi dari lingkunga sekitar.

Partisipan dalam penelitian ini adalah para pengidap HIV/AIDS yang dipilih berdasarkan pada kriteria yang telah ditentukan sesuai dengan tujuan penelitian. Kriteriakriteria tersebut adalah: (1) orang dengan HIV/AIDS, (2) berada pada kategori usia dewasa 
awal, dan (3) individu yang bersedia menjadi subjek penelitian. Pengambilan subjek penelitian dengan menggunakan teknik snowball.

\section{Pengumpulan dan Analisis Data}

Pengumpulan data dalam penelitian ini menggunakan wawancara semi terstruktur. Ada hal-hal yang disampaikan kepada subjek penelitian sebelum dilakukan proses wawancara, yaitu: (1) tujuan dan kepentingan peneliti, (2) kerahasiaan, (3) prosedur penelitian, dan (4) persiapan untuk memulai wawancara. Metode analisis data yang digunakan dalam penelitian ini adalah Teknik eksplikasi data. Teknik ini merupakan Teknik analisis data yang mencakup beberapa langkah, yaitu: (1) memperoleh pemahaman data sebagai suatu keseluruhan, (2) menyusun Deskripsi Fenomena Individual (DFI), (3) mengidentifikasi episode-episode di setiap DFI, (4) eksplikasi tema-tema pada setiap episode, dan (5) sintesis dari penjelasan setiap tema dalam setiap episode.

\section{Hasil dan Pembahasan}

Ketiga partisipan dalam penelitian ini mengalami perlakuan berbeda dalam proses pengasuhan keluarganya. Menurut Diana Baumrind ada beberapa pola atau gaya pengasuhan dalam keluarga, yaitu pengasuhan otoritarian, pengasuhan otoritatif, pengasuhan yang melalaikan, dan pengasuhan yang memanjakan. Ketiga partisipan tersebut masing-masing mengalami pola pengasuhan otoritarian, pola pengasuhan yang melalaikan, dan pola pengasuhan yang memajakan pada masa kanak-kanak.

Berkaitan asal muasal terjangkitnya penyakit pada ketiga partisipan ini juga berbeda. Ada yang tertular HIV/AIDS dari pasangannya (suaminya) yang memang menjadi pecandu narkoba. Sedangkan partisipan yang lain tertular HIV/AIDS karena memang ia menggunakan narkoba. Memang sudah diketahui secara umum bahwa penularan penyakit ini dapat terjadi melalui jarum suntik (narkoba atau saat suntik obat yang menggunakan jarum tidak steril), hubungan seksual, dan melalui air susu ibu.

Ketiga partisipan juga mengalami stigma dan diskriminasi di lingkungan sekitarnya secara berbeda. Pertisipan pertama (A) mengalami perlakuan yang kurang menyenangkan dari keluarga besarnya. Keluarga besar A tidak mau mengunjungi atau berinteraksi pada keluarga A. Bahkan, saat mereka bersentuhan secara tak sengaja saja mereka langsung mengambil air wudhu. Partisipan kedua (B) pengalami perlakuan yang hampir serupa. Di dalam keluarga, alat-alat makan B dipisahkan dari keluarganya. Tidak hanya keluarga, lingkungan kerja B (puskesmas) juga melakukan hal yang sama. Ada beberapa rekan kerja 
yang membentak dan memarahinya saat melaksanakan pekerjaannya. Partisipan ketiga (C) mengalami stigma dan diskriminasi yang berbeda. la harus mendapati kenyataan bahwa anaknya juga tertular HIV/AIDS hingga meninggal. Beban psikologisnya semakin berat karena la juga sudah tidak memiliki kekuatan fisik karena harus terbaring karena sakitnya.

Beban hidup dari tekanan psikologis dan kondisi fisik yang makin memburuk, membuat ketiga partisipan ini memiliki pandangan berbeda tentang makna hidupnya. Ada partisipan yang memaknai hidupnya sebagai umat Tuhan yang harus menerima segala cobaan dan kondisi yang ditimpakan padanya. Partisipan lain menganggap bahwa kondisi yang harus diterimanya sekarang merupakan bentuk dosa dari masa lalunya. Hal ini merupakan salah satu bentuk aspek resiliensi, yaitu kemampuan menganalisis masalah. Artinya, la mampu menganalisis berbagai penyebab yang mengakibatkan kondisinya pada saat ini.

Partisipan lainnya memaknai hidupnya dengan berbeda. la mengartikan garis hidup yang harus diterimanya saat ini merupakan bentuk peringatan dari Tuhan bahwa hidupnya tidak akan lama lagi. Untuk itulah, la tidak pernah menyalahkan suaminya yang telah menularkan penyakit padanya. la juga menganalisis bahwa penyakit yang dialaminya kini merupakan bentuk konsekuensinya karena telah memilih menikah dengan orang yang tidak tepat (mengidap HIV/AIDS). Karena awalnya, la memutuskan menikah sebagai pelampiasan kekecewaan pada mantan suami pertamanya. Apalagi pernikahan keduanya tidak meminta izin dari keluarga besarnya sebagai bentuk perlawanan terhadap bentuk otoriter keluarganya. Akhirnya, la memutuskan untuk memanfaatkan sisa hidupnya dengan melakukan sesuatu yang dapat bermanfaat bagi orang lain. Salah satunya bergabung dengan Yayasan Peduli Kasih di Semarang.

\section{Kesimpulan Penelitian}

Berdasarkan penelitian yang telah dilakukan terhadap tiga partisipan tersebut, peneliti menemukan bahwa masing-masing partisipan memiliki dinamika psikologis yang berbeda dalam menjalani hidupnya. Latar belakang pengasuhan pada masa kanak-kanak berpengaruh besar terhadap partisipan terjangkit virus HIV/AIDS. Ada yang tertular dari suaminya dan ada pula yang tertular karena narkoba (penggunaan jarum suntik yang tidak steril). Perlakuan, stigma, dan diskriminasi yang ditimpakan kepada ketiga partisipan dari keluarga dan lingkungannya juga berbeda. Ada yang dikucilkan dari keluarga besar, ada 
yang diperlakukan secara berbeda hingga ke hal-hal terkecil (pemisahan peralatan makan), dan ada pula yang yang diperlakukan kasar di tempat kerjanya.

Ketiga partisipan juga berbeda dalam memaknai hidupnya pasca tervonis mengidap HIV/AIDS. Ada partisipan yang menganggap bahwa penyakitnya merupakan cobaan dari Tuhan. Ada yang menganggap juga bahwa penyakit HIV/AIDS yang dialaminya saat itu sebagai bentuk hukuman dari perbuatan masa lalu yang dilakukannya. Partisipan lain memaknai hidupnya sebagai bentuk peringatan bahwa hidupnya tidak akan panjang. Karena itulah, ia tidak pernah menyalahkan orang lain sebagai penyebab penyakitnya dan lebih tertarik untuk beraktivitas pada kegiatan yang memberi manfaat bagi orang lain.

\section{KESIMPULAN}

Penelitian kualitatif merupakan penelitian yang bersumber pada filsafat postpositivisme. Penelitian ini hadir sebagai bentuk kritik terhadap penelitian kuantitatif karena tidak mampu lagi menjawab segala persoalan yang dialami masyarakat saat ini. Kuantitatif sebagai metode penelitian tertua dianggap tidak mampu lagi memberi solusi terhadap berbagai peliknya masalah individu dalam interaksi sosialnya.

Jika berbicara tentang sejarah kemunculannya, penelitian kualitatif dan kuantitatif lahir hampir bersamaan. Penelitian kuantitatif lebih cepat berkembang saat itu sehingga tercipta semacam pandangan bahwa penelitian ini muncul terlebih dahulu. Beberapa dekade belakangan ini, perkembangan penelitian kualitatif semakin meluas. Metode ini tidak hanya digunakan dalam disiplin ilmu sosial semata tetapi juga sudah merambah ke disiplin ilmu terapan juga. Salah satu fakta yang menyatakan bahwa penelitian kualitatif mulai dilirik oleh orang-orang kuantitatif adalah berkembangnya wacana tentang metode kombinasi atau Mix Methods. Perpaduan atau kombiansi kedua jenis metode ini, dimaknai sebagai realitas bahwa orang-orang kunatitatif sudah mulai membuka diri untuk penelitian kualitatif.

Penelitian kualiattif terbagi menjadi beberapa bagian, antara lain penelitian fenomenologi. etnografi, studi kasus, analisis konten, dan gounded theory. Dalam artikel ini, pembahasan difokuskan pada pendekatan fenomenologi. Pendekatan fenomenologi merupakan pendekatan penelitian yang mencoba menggali dan menemukan pengalaman hidup manusia terhadap diri dan hidupnya. Salah satu contoh penelitian yang dibahas dalam artikel ini adalah penelitian fenomenologi bagi para pengidap HIV/AIDS. Penelitian ini mengkaji secara mendalam perspektif para partisispan sebagai pengidap HIV/AIDS dalam memaknai hidupnya. Hal ini dirasakan menarik karena pada kenyataannya, para pengidap HIV/AIDS tersebut mengalami stigma, 
penolakan, perlakuan diskrimasi dari keluarga dan lingkungan sekitarnya. Secara psikis, beban moral yang ditanggung oleh para pengidap penyakit ini sangat berat.

\section{Daftar Pustaka}

Alase, Abayomi. 2017. The Interpretative Phenomenological Analysis (IPA): A Guide to a Good Qualitative Reseach Approach. International Journal of Education and Literacy Studies, Vol. 5 No. 2, April 2017. DOI: 10.7575/aiac.ijels.v.5n.2p.9

Almalki, Sami. 2016. Integrating Quantitative and qualitative Data in Mixed Methods ResearchChalenges and Benefits. Journal of Education and Learning, vol. 5, No. 3, Hlm. 288-296. Doi: 10.5539/jel.v5n3p288

Bayir, Aidan dan Tim Lomas. 2016. Difficulties Generating Self-compassion: An Interpretative Phenomenological Analysis. The Journal of Happiness \& Well-Being, Vol. 4 No. 1. HIm. 1533.

Brady, Shane R. 2015. Utilizing and Adapting the Delphi Method for Use in Qualitative Research. International Journal of Qualitative Methods, hlm. 1—6. DOI: 10.1177/1609406915621381

Eddles-Hirsch, Katrina. 2015. Phenomenology and Educational Research. International Journal of Advanced Research, Vol. 3 Issue 8, Agustus 2015.

Hashemnezhad, Hossein. 2015. Qualitative Content Analysis Research: A Review Article. Journal of ELT and Applied Linguistics, Vol. 3 Issue 1, Maret 2015. HIm. 54-62.

Hilal, Alyahmady Hamed dan Saleh Said Alabri. 2013. Using NVIVO for Data Analysis in Qualitative Research. International Interdisciplinary Journal of Education, Vol 2, Issue 2, HIm. $181-186$.

Indriani, Septiana Dewi dan Nailul Fauziah. 2017. Karena Hldup harus terus Berjalan (Sebuah Studi Fenomenologi Kehidupan Orang dengan HIV/AIDS). Jurnal Empati, Vol. 6(1), Januari 2017. HIm. 385-395.

Irianto dan Subandi. 2015. Studi Fenomenologis Kebahagiaan Guru di Papua. Gadjah Mada Journal of Psychology, Vol 1, No. 3 September 2015. HIm. 140-166.

Khan, Shahid N. 2014. Qualitative Research Method-Phenomenology. Asian Social Science, Vol. 10 No. 21, Oktober 2014. DOI: 10.5539/ass.v10n21p298

Mujib, Abdul. 2015. Pendekatan Fenomenologi dalam Studi Islam. Al-Tadzkiyyah: Jurnal Pendidikan Islam, Vol. 6, Desember 2015. HIm. 167-183.

Nassaji, Hossein. 2015. Qualitative and Descriptive Research: Data Type Versus Data Analysis. Editorial Language Teaching Research, Vol 19(2), HIm. 129-132. DOI: $10.1177 / 1362168815572747$

Newman, W. Lawrence. 2014. Social Research Methods: Qualitative and Quantitative Approaches. New Jersey: Pearson 
Oun, Musab A. dan Christian Bach. 2014. Qualitative Research Method Summary. Jornal of Multidisciplinary Engineering and Science and Technology, Vol. 1, Issue 5, Desember 2014.

Padilla-Diaz, Mariwilda. 2015. Phenomenology in Educational Qualitative Research: Philosophy as Science or Philosophical Science? International Journal of Educational Excellence, Vol 1 No. 2. HIm. 101-110.

Putra, Nusa dan Ninin Dwilestari. 2016. Penelitian Kualitatif PAUD. Jakarta: Rajawali Pers

Sani, Ridwan Abdullah, sondang R. Manurung, Hary Suswanto, dan Sudiran. 2017. Penelitian Pendidikan. Tangerang: TSmart

Snelson, Chareen L. 2016. Qualitative and Mixed Methods Social Media Research: A Review of Literature. International Journal of Qualitative Methods. Hlm. 1-15. DOI: $10.1177 / 1609406915624574$

Sohn, Brian Kelleher dkk. 2017. Hearing The Voices of Students and Teachers: A Phenomenological Approach to Educational Research. Qualitative Research in Education, Vol. 6 No. 2, Juni 2017. DOI: 10.17583/qre.2017.2374

Strauss, Anselm dan Juliet Corbin. 2017. Dasar-dasar Penelitian Kualitatif. Yogyakarta: Pustaka Pelajar

Tuffour, Isaac. 2017. A Critical Overview of Interpretative Phenomenological Analysis: A Contemporary Qualitative Research Approach. Journal of Healthcare Communications. Vol. 2 No. 4, Juli 2017. DOI: 10.4172/2472-1654.100093

Yuksel, Pelin dan Sonel Yildirim. 2015. Theoretical Frameworks, Methods, and Procedures for Conducting Phenomenological Studies in Educational Settings. Turkish Online Journal of Qualitative Inquiry, Vol. 6, No. 1, Januari 2015. 